\title{
IS LOW BIRTH WEIGHT ASSOCIATED WITH CONGENITAL HEART DISEASE?
}

\author{
Nutan Nalini Bage ${ }^{1}$, Atul Mukul Bage ${ }^{2}$ \\ ${ }_{1}^{1}$ Associate Professor, Department of Anatomy, PIMS, Pondicherry. \\ 2Professor, Department of ENT, SMVMCH, Pondicherry.
}

\section{ABSTRACT}

\section{BACKGROUND}

Daily we see lots of still birth cases and the agony associated with it after carrying the fetus for so many months with the negative outcome it is quite disheartening. Malnutrition is quite rampant in the country as far as the females are concerned and in the name of the religion and rituals, it complicates the issue further. If the mother is malnourished, the chance of low birth weight baby is high.

\section{OBJECTIVES}

To correlate the prevalence of cardiac anomalies in low birth weight fetuses.

\section{MATERIAL AND METHOD}

The study was carried out in 40 stillbirth fetuses with detailed account of nutritional status of the mother, consanguinity, history of previous pregnancies, miscarriages, socio-economic status and exposure to drugs/radiation. The number of cases with fetus having cardiac anomalies was quite significant.

\section{RESULTS}

Out of total 40 stillbirth fetuses, 29 (72.5\%) stillbirths were from less than $2.5 \mathrm{~kg}$ and $11(27.5 \%)$ were from more than $2.5 \mathrm{~kg}$. Cardiac anomalies were present in 16 and 02 cases respectively. Fused heart-01, mesocardia-01, Dextrocardia with CORV-02, Interrupted aortic arch-02, Abnormal origin of right subclavian artery-01, Tetralogy of Fallot-01, VSD-07, ASD-01, transposition of great vessels-01, persistent truncus arteriosus with tricuspid atresia, elongated hypertrophied abnormally positioned Rt. Atrium, rudimentary Rt. Ventricle-01, mal-attachment of ductus arteriosus-03, double superior vena cava-01, dilated caval system-01.

\section{CONCLUSION}

Considering the high incidence of cardiac anomalies in fetuses of low birth weight, we must try to create awareness and support the expectant mothers to avoid the low birth weight babies and thus the congenital anomalies.

\section{KEYWORDS}

Still birth, Low Birth Weight (LBW), Congenital Heart Disease (CHD).

HOW TO CITE THIS ARTICLE: Bage NN, Bage AM. Is low birth weight associated with congenital heart disease? J. Evolution Med. Dent. Sci. 2016;5(18):893-896, DOI: 10.14260/jemds/2016/206

\section{INTRODUCTION}

In this study we wanted to know-is there any association of the low birth weight fetus and cardiac defects? The causes are many for cardiac anomalies including poor socio-economic status, exposure to drugs/radiation, consanguineous marriages. Poor nutrition means there is every possibility that the baby would be of low birth weight. Malnutrition is quite rampant in the country as far as the females are concerned, in the name of the religion and rituals it is further compounded. With low birth weight baby the chances of cardiac and extracardiac anomalies are very high. Low body weight in cardiology is deemed as $2.5 \mathrm{~kg}$ or below. $(1,2,3)$ though it can be $2.0 \mathrm{~kg}$ and below. $(4,5)$

Establishing the prevalence of Low Birth Weight (LBW) is particularly important, since perinatal morbidity and mortality are more frequent in LBW than in normal infants and has become the second cause of death in this period, after

Financial or Other, Competing Interest: None.

Submission 18-01-2016, Peer Review 13-02-2016,

Acceptance 19-02-2016, Published 01-03-2016.

Corresponding Author:

Dr. Atul Mukul Bage,

Plot No. 39,40. Messiah Street,

Raja Annamalainagar, Gorimedu,

Pondicherry-605006.

E-mail: atulbage@yahoo.co.in

DOI: $10.14260 /$ jemds $/ 2016 / 206$ premature birth.(6) Furthermore, socio-economic factors like habitat, education, birth order, age and religion also affect birth weight.(7) Moreover, women born with LBW are more likely to give birth to infants with LBW, contributing to the transgenerational cycle of malnutrition and poverty.(8) Among other causes of stillbirth, the small for gestational age fetus had an incidence of stillbirth of 46.8 per 1000 , whereas the appropriate-for-gestational-age fetus had a rate of 4.0 per 1000.(9)

\section{MATERIAL AND METHODS}

A total number of 40 stillbirth fetuses of varying gestational age of both sexes of known and unknown causes were procured from the Department of Obstetrics and Gynaecology, JIPMER. The study was conducted in the Department of Anatomy, JIPMER, Pondicherry. Detailed history of mother was taken, especially in terms of nutritional status, consanguinity, history of previous pregnancies, miscarriages, socio-economic status and exposure to drugs/radiation, possible cause of fetal death and mode of termination.

Consent for autopsy and embalming was obtained from the parents, the fetuses were subjected to detailed external physical examination and the anomalies were noted. A midline incision was given below the chin to pubic symphysis to open the neck, thorax and peritoneal cavity. The detailed anomalies both cardiac and extracardiac was recorded and analysed. In 
this article, we are emphasizing only the cardiac defects which were associated with low birth weight.

\section{RESULTS}

\begin{tabular}{|c|c|c|c|c|c|}
\hline \multirow{2}{*}{ Weight } & \multicolumn{4}{|c|}{ CVS Malformations } & \multirow{2}{*}{ Total } \\
\cline { 2 - 5 } & \multicolumn{2}{|c|}{ Present } & \multicolumn{2}{|c|}{ Absent } & \\
\hline$<2.5 \mathrm{~kg}$ & 16 & $55.17 \%$ & 13 & $44.83 \%$ & 29 \\
\hline$>2.5 \mathrm{~kg}$ & 02 & $18.18 \%$ & 09 & $81.82 \%$ & 11 \\
\hline \multicolumn{5}{|c|}{ Table 1 } \\
\hline
\end{tabular}

Chi sq. - 4.409. Degrees 0 - 1. P- Value - 0.0357

Table 1 shows the CVS malformation in $<2.5 \mathrm{~kg}$ of birth weight fetus present in 16 (55.17\%) and absent in 13 $(44.83 \%)$, total no. $=29$. In $>2.5 \mathrm{~kg}$ the defects were found in only $02(18.18 \%)$ and absent in $09(81.82 \%)$ cases, total no. $=11$. P-value -0.0357 .

\begin{tabular}{|c|c|}
\hline $\begin{array}{c}\text { CARDIAC AND GREAT VESSELS } \\
\text { ANOMALIES }\end{array}$ & NO. \\
\hline Fused heart & 01 \\
\hline Mesocardia & 01 \\
\hline Dextrocardia with CORV & 02 \\
\hline Interrupted aortic arch & 02 \\
\hline $\begin{array}{c}\text { Abnormal origin of right } \\
\text { subclavian artery }\end{array}$ & 01 \\
\hline Tetralogy of Fallot & 01 \\
\hline V.S.D & 07 \\
\hline A.S.D & 01 \\
\hline $\begin{array}{c}\text { Transposition of great vessels } \\
\text { Persistent truncus arteriosus } \\
\text { with tricuspid atresia, } \\
\text { elongated hypertrophied } \\
\text { abnormally positioned Rt. }\end{array}$ & 01 \\
\hline Atrium, rudimentary Rt. Ventricle & 01 \\
\hline Mal-attachment of ductus arteriosus & 03 \\
\hline Double superior vena cava & 01 \\
\hline Dilated caval system & 01 \\
\hline Table 2 \\
\hline
\end{tabular}

Table 2 showing the different types of cardiac malformation, which was found during dissection. Fused heart-01, mesocardia-01, dextrocardia with CORV-02, interrupted aortic arch-02, abnormal origin of right subclavian artery-01, Tetralogy of Fallot-01, V.S.D-07, ASD-01, transposition of great vessel-01, persistent truncus arteriosus with tricuspid atresia, elongated hypertrophied abnormally positioned Rt. Atrium, rudimentary Rt. Ventricle-01, malattachment of ductus arteriosus-03, double superior vena cava-01, dilated caval system- 01 .

\section{DISCUSSION}

Stillbirth pregnancies are associated with increased prevalence of Small for Gestational Age (SGA) fetuses compared with live births. In fact, the risk of stillbirth increases with declining percentile of birth weight.(10)

However, it is fetal growth impairment and not small fetal size that is associated with stillbirth. Unlike SGA fetuses, the fetuses with impaired growth are those that are smaller than expected after physiologic factors determining fetal size were considered. A study of over 300,000 pregnancies clearly demonstrated that stillbirth is more frequent only among these foetuses.(11)

The cross-sectional studies of association between fetal size and growth and stillbirth have a significant limitation. The time of death is not precisely known and gestational age at delivery might be considerably longer than at the time of demise, falsely increasing incidence of SGA and growth restricted fetuses. Despite this uncertainty, the relation between fetal growth impairment and stillbirth seems real. Several recent studies demonstrated strong, "Dose dependent" and biologically plausible associations between concentration of early or mid-pregnancy placental hormones and stillbirth.(12,13,14)

In contrast, for live births the frequency of congenital heart defects in various epidemiological studies has ranged between 4 and 8 per 1000.(15-18) Necropsies on neonates (Still births and live born infants dying shortly after birth) have shown incidence rates for congenital heart defects varying between $6 \%$ and $13 \% .(19-24)$

Max Godfrey, et al.(25) in their observation shows a sevenfold higher incidence of CHD in the VLBW neonates and an eleven-fold higher incidence in the extremely low birth weight population as compared to the reported incidence of $0.5-0.8 \%$ in the general population.(26-28) A population-based study has shown low birth weight, small for gestational age and preterm birth to be associated with many forms of CHD.(29) Interestingly, transposition of the great arteries and aortic stenosis were not associated with these variables in that study.

A more recent study of non-syndromatic CHD showed a two-fold increase in likelihood of being small for gestational age, a three-fold increased risk of prematurity and a reduced mean birth weight in the CHD population.(30) The latter study found the associations to be valid for all types of CHD tested. Their results did not show a statistically significant relationship between birth weight and incidence of CHD within the VLBW population, although this may have been due to the small numbers involved. It could represent a true increase in CHD in the VLBW population. The reasons for the higher incidence of CHD observed in premature infants remain unclear. They speculated that it may be due to the fact that small septal defects close spontaneously in utero and thus fewer may be apparent in mature infants.

This would not, however, explain the reported increased incidence of non-septal defects in our LBW population. It is also possible that CHD may be independently associated with premature birth and/or low birth weight. It is generally accepted that the causes of CHD are multifactorial involving a wide range of genetic (Including non-syndromatic) and environmental risk factors.(31,32) Thus, prematurity and/or intrauterine growth retardation or small for gestational age weight may be causally related to the same factor(s) that precipitated the CHD.

C Tennstedt, R Chaoui, et al.(33) found in their study of aborted fetuses, ventricular septal defect the most common defect (28\%). In no case did it occur as an isolated lesion. In $56 \%$, it was associated with other cardiovascular anomalies (Double outlet right ventricle, coarctation of the aorta, Tetralogy of Fallot, tricuspid atresia, atrial septal defect, transposition of the great arteries and truncus arteriosus communis. Ventricular septal defect has been reported to be the most frequent cardiac defect in various other necropsy studies of live births and stillbirths. ${ }^{(19,20)}$ and in those studies the proportion was higher than in ours (Between $32 \%$ and $42 \%$ ). We totally agree that VSD is the most common finding always clubbed with other anomalies. 
Infants with congenital malformations have on average lower birth weight than do infants without malformations with a few exceptions. $(34,35)$ The relation between growth restriction and malformations may be explained by either the growth restriction as primary and predisposing the fetus to malformations or as secondary to the presence of malformations or by coexisting with a malformation due to common etiologic factor(s).(34,35)

\section{CONCLUSION}

It is amply clear from our reports and the review of literature and discussion that definitely there is a correlation between CHD and low birth weight fetus. The era is different and with the advent of latest equipment we can prevent the poor outcome. What we personally believe is awareness is the key and with it at least we can minimize the tragedies.

\section{REFERENCES}

1. Ades AM, Dominguez TE, Nicolson SC, et al. Morbidity and mortality after surgery for congenital cardiac disease in the infant born with low weight. Cardiol Young 2010;20(1):817.

2. Bové T, François $\mathrm{K}$, De Groote $\mathrm{K}$, et al. Outcome analysis of major cardiac operations in low weight neonates. Ann Thorac Surg 2004;78(1):181-7.

3. Pawade A, Waterson $\mathrm{K}$, Laussen $\mathrm{P}$, et al. Cardiopulmonary bypass in neonates weighing less than $2.5 \mathrm{~kg}$ : analysis of the risk factors for early and late mortality. J Card Surg 1993;8(1):1-8.

4. Roussin R, Belli E, Bruniaux J, et al. Surgery for transposition of the great arteries in neonates weighing less than 2000 grams: a consecutive series of 25 patients. Ann Thorac Surg 2007;83(1):173-7. Discussion 177-8.

5. Quaegebeur JM, Jonas RA, Weinberg AD, et al. Outcomes in seriously ill neonates with coarctation of the aorta. A multiinstitutional study. J Thorac Cardiovasc Surg 1994;108(5):841-51. Discussion 852-4.

6. Thornton JG. Perinatal mortality rises both with prematurity and with the degree to which the baby's birth weight is below that expected for gestational age. Eur J Obstet Gynecol Reprod Biol 2001;95(1):5.

7. Gagan ASA, Kapil G, Vijay K, et al. Maternal risk factors associated with low birth weight neonates in a tertiary care hospital, Northern India. J Community Med Health Educ 2012;02(9):177-80.

8. Roberfroid D, Huybregts L, Lanou H, et al. Effects of maternal multiple micronutrient supplementation on fetal growth: a double-blind randomized controlled trial in rural Burkina Faso. Am J Clin Nutr 2008;88(5):1330-40.

9. Fretts RC, Boyd ME, Usher RH, et al. The changing pattern of fetal death 1961-1988. Obstet Gynecol 1992;79:35-9.

10. Manning F. Fetal Medicine Principles and Practice. Norwalk: Appleton and Lange; 1995. Intrauterine growth restriction; p. 317.

11. Clausson B, Gardosi J, Francis A, et al. Perinatal outcome in SGA births defined by customised versus population-based birth weight standards. Bjog 2001;108(8):830-4. [PubMed]

12. Smith GC, Crossley JA, Aitken DA, et al. First-trimester placentation and the risk of antepartum stillbirth. Jama 2004;292(18):2249-54. [PubMed]
13. Dugoff L, Hobbins J, Malone F, et al. Quad screen as a predictor of adverse pregnancy outcome. Obstet Gynecol 2005;106:260-67. [PubMed]

14. Smith GC, Stenhouse EJ, Crossley JA, et al. Early pregnancy levels of pregnancy-associated plasma protein and the risk of intrauterine growth restriction, premature birth, preeclampsia and stillbirth. J Clin Endocrinol Metab 2002;87(4):1762-7. [PubMed]

15. Ferencz C, Rubin JD, Loffredo CA, et al. Epidemiology of congenital heart disease: the Baltimore-Washington Infant Study 1981-1989. Mount Kisko: Futura, 1993;33-73.

16. Ferencz C, Rubin JD, McCarter RJ, et al. Congenital heart disease: prevalence at live birth. The BaltimoreWashington Infant Study. Am J Epidemiol 1985;121:31-6.

17. Hoffmann JIE, Christianson R. Congenital heart disease in a cohort of 19502 birth with long-term follow-up. Am J Cardiol 1978;42:641-7.

18. Mitchell SC, Corones SB, Berendes HW. Congenital heart disease in 56109 births. Circulation 1971;43:323-32.

19. Samanek M, Goetzova J, Benesova D. Distribution of congenital heart malformations in an autopsied child population. Int J Cardiol 1985;8:235-50.

20. Tennstedt A, Gutermann M, Schreiber D. Malformations of the heart and vascular system in autopsy material of children. Z Allg Pathol Anat 1983;128:127-32.

21. Laursen HB. Some epidemiological aspects of congenital heart disease in Denmark. Acta Paediatr Scand 1980;69:619-24.

22. Goetzova J, Benesova D. Angeborene Herzfehler im Sektionsmaterial totgeborener und verstorbener Kinder im mittelböhmischen Bezirk in den Jahren 1967-1976. Cesk Pediatr 1979;34:547-50.

23. Jaiyesimi F, Antia AU. Extracardiac defects in children with congenital heart disease. Br Heart J 1979;42:475-9.

24. Schultrich S. Die angeborenen Herzfehler im Sektionsmaterial des Pathologischen Universitätsinstituts Leipzig. Z Allg Pathol Anat 1977;121:429-39.

25. Max Godfrey, Michael S Schimmel, Cathy Hammerman. The incidence of congenital heart defects in very low birth weight and extremely low birth weight infants. IMAJ 2010;12:36-38.

26. Samanek M, Vorıskova M. Congenital heart disease among 815,569 children born between 1980 and 1990 and their 15-year survival: a prospective Bohemia survival study. Pediatr Cardiol 1999;20:411-17.

27. Wren C, Richmond S, Donaldson L. Presentation of congenital heart disease in infancy: implications for routine examination. Arch Dis Child Fetal Neonatal Ed 1999;80:49-53.

28. Wren C, Richmond S, Donaldson L. Temporal variability in birth prevalence of cardiovascular malformations. Heart 2000;83:414-19.

29. Rosenthal GL, Wilson PD, Permutt T, et al. Birth weight and cardiovascular malformations: a population-based study (The Baltimore-Washington Infant Study). Am J Epidemiol 1991;133:1273-81.

30. Malik S, Cleves MA, Zhao W, et al. The national birth defects prevention study. Association between congenital heart defects and small for gestational age. Paediatrics 2007;119:976-82. 
31. Jenkins KJ, Correa A, Feinstein JA, et al. Non-inherited risk factors and congenital cardiovascular defects: current knowledge: a scientific statement from the American Heart Association Council on Cardiovascular Disease in the young: endorsed by the American Academy of Paediatrics. Circulation 2007;115:2995-3014.

32. Pierpont ME, Basson CT, Benson DW Jr, et al. Genetic basis for congenital heart defects: current knowledge, a scientific statement from the American Heart Association Congenital Cardiac Defects Committee, Council on Cardiovascular Disease in the Young: endorsed by the American Academy of Paediatrics. Circulation 2007;115:3015-38.
33. Tennstedt C, Chaoui R, Körner H, et al. Spectrum of congenital heart defects and extracardiac malformations associated with chromosomal abnormalities: results of a seven year necropsy study. Heart 1999;82:34-39.

34. Khoury MJ, Erickson JD, Cordero JF, et al. Congenital malformations and intrauterine growth retardation: a population study. Paediatrics 1988;82:83-90.

35. Mili F, Edmonds LD, Khoury MJ, et al. Prevalence of birth defects among low-birth-weight infants. A population study. Am J Dis Child 1991;145:1313-18. 